\title{
The Doctorate Journey: Mapping Perceptions of the Ph.D. Process
}

\section{Dr. Stephanie Cutler, Pennsylvania State University, University Park}

Stephanie Cutler has a Ph.D. in Engineering Education from Virginia Tech. Her dissertation explored faculty adoption of research-based instructional strategies in the statics classroom. Currently, Dr. Cutler works as an assessment and instructional support specialist with the Leonhard Center for the Enhancement of Engineering Education at Penn State. She aids in the educational assessment of faculty-led projects while also supporting instructors to improve their teaching in the classroom. Previously, Dr. Cutler worked as the research specialist with the Rothwell Center for Teaching and Learning Excellence Worldwide Campus (CTLE - W) for Embry-Riddle Aeronautical University.

\section{Dr. James J. Pembridge, Embry-Riddle Aeronautical Univ., Daytona Beach}

James J. Pembridge is an Assistant Professor in the Freshman Engineering Department at Embry-Riddle Aeronautical University. He earned a B.S. in Aerospace Engineering, M.A. Education in Curriculum and Instruction, and Ph.D. in Engineering Education from Virginia Tech. His research has focused on mentoring as pedagogy for project-based courses and understanding the adult learning characteristics of undergraduate students.

\section{Dr. Matthew A. Verleger, Embry-Riddle Aeronautical Univ., Daytona Beach}

Matthew Verleger is an Assistant Professor of Engineering Fundamentals at Embry-Riddle Aeronautical University in Daytona Beach, Florida. His research interests are focused on using action research methodologies to develop immediate, measurable improvements in classroom instruction and the use of Model-Eliciting Activities (MEAs) in teaching students about engineering problem solving. Dr. Verleger is an active member of ASEE. He also serves as the developer and site manager for the Model-Eliciting Activities Learning System (MEALearning.com), a site designed for implementing, managing, and researching MEAs in large classes. 


\title{
The Doctorate Journey: Mapping perceptions of the $\mathrm{PhD}$ process
}

\begin{abstract}
During a special session at the Frontiers in Education conference in 2013, presenters used an analogy to the fantasy book/movie series The Lord of the Rings by J.R.R. Tolkien ${ }^{1}$ framed by identity-trajectory theory to explore the pathway to receiving a $\mathrm{PhD}^{2}$. At the start of the session, participants were asked to create a map of the $\mathrm{PhD}$ process keeping the following questions in mind: Who are the players and how do they relate to each other?; What are the milestones?; and What are the events that impact the outcomes?
\end{abstract}

Using the participant-created maps as well as original analogy elements, this paper explores the elements of identity-trajectory highlighted by the different participant group maps. Academic identity-trajectory includes three primary elements: intellectual, institutional, and network ${ }^{3,4}$. For the intellectual element, we explore the role of the overall field in the $\mathrm{PhD}$ process and how they were represented within the participant created maps. The institutional element helps explore the graduate school structure and resources that influence graduate students' development. Largely, the institutional elements are highlighted through the required milestones that must be overcome to complete the $\mathrm{PhD}$ process. Finally, the network element explores the relationships that influence graduate students and the role these different players influence a graduate student's success in receiving their $\mathrm{PhD}$. Additionally, we highlight the challenges or events that can negatively impact a student's progress toward degree as identified by the special session participants.

The goal of this paper is to demonstrate multiple perceptions of the $\mathrm{PhD}$ process to aid current and future graduate students in understanding common pathways and to help initiate conversations among graduate students and other players about what to expect from the PhD process. Good communication between an advisor/advisee, and among various graduate students, can help to negate some of the challenges students face in graduate school and encourage a successful experience for the students.

\section{Background}

Analogies and metaphors have been used to examine complex social interactions and processes as support mechanisms to establish relatedness and empathy of the intended context ${ }^{5}$. At the 2013 IEEE/ASEE Frontiers in Education conference ${ }^{2}$, The Lord of the Rings by J.R.R. Tolkien ${ }^{1}$ was paralleled to the graduate student experience. An adapted version of the handout provided at the session is included in Appendix A to offer an overview of The Lord of the Rings elements and characters used in the analogy and how they are situated in the original work as well as within the $\mathrm{PhD}$ process. The analogy allowed for a structured discussion about the different milestones, characters, and events that influence the $\mathrm{PhD}$ process. To help participants start thinking about the process, the session began with participant groups creating a road map for their journey through the PhD process.

Within the United States, the completion rate for $\mathrm{PhD}$ students is between $45-65 \%{ }^{6}$. There are a variety of causes that contribute to students leaving their programs ${ }^{7}$, including unclear expectations of the process for completing a $\mathrm{PhD}^{8,9}$. This paper, like the special session, will be framed around identity trajectory theory and will present multiple maps created by special session participants to catalyze a discussion of the institutional, intellectual, and networking elements that are present on many $\mathrm{PhD}$ journeys.

The overall purpose of this paper is to present multiple pathways for successfully completing the $\mathrm{PhD}$ journey and to highlight some often overlooked elements of the process that can slow or even halt student progress. Additionally, this paper is meant to catalyze conversation among graduate students, 
undergraduate students, advising faculty members, and administrators about the specifics of the pathway to a $\mathrm{PhD}$. The elements of the $\mathrm{PhD}$ process that are highlighted with the analogy presented at the special session are the interpretation of the facilitators. Our interpretation might not resonate with every $\mathrm{PhD}$ student or every reader, but discussing the differences and shortcomings of the analogy will still initiate more detailed conversations about the $\mathrm{PhD}$ process and the implications of the differences between our interpretations and that of others.

\section{Framework}

To help guide their exploration, participants were provided an overview of identity-trajectory theory during the special session to support their reflection of their experience towards earning a $\mathrm{PhD}$. Identitytrajectory was also used to help frame the analogy for the special session to support the analysis of the participant maps as well. Academic identity-trajectory consists of three major strands: intellectual, network, and institutional ${ }^{3,4}$. The intellectual strand refers to how a student becomes part of and contributes to their overall academic field ${ }^{3}$. In this study, the intellectual element explores the role of the overall disciplinary field with respect to the $\mathrm{PhD}$ process. The institutional strand refers to the more specific elements of the student's department or university ${ }^{3}$. In this study, the institutional elements will be represented by graduate school structural elements and resources that influence graduate student development. Largely, the institutional elements are highlighted through the required milestones that must be overcome to complete the $\mathrm{PhD}$ process. Finally, the network strand refers to the student's connection to different networks and collaborations ${ }^{3}$. Here, the network strand explores the relationships that influence the graduate students and will be closely tied to the different players that influence a graduate student's success in receiving their $\mathrm{PhD}$.

\section{Participants}

Approximately 25-30 participants were present at the FIE special session and were divided into five groups. No participant names or identifying information was collected. From facilitator observation, participants included current graduate students, recently graduated $\mathrm{PhDs}$, and experienced faculty who had advised multiple $\mathrm{PhD}$ students throughout their careers. The disciplines of the participants were not identified, but, from the nature of the FIE conference, it is assumed that a majority of the participants were from engineering disciplines. The session leaders, as well as many of the session participants, hold $\mathrm{PhDs}$ in Engineering Education from Purdue or Virginia Tech. The session tried to maintain a focus that was not exclusively built around the $\mathrm{PhD}$ process in Engineering Education at those two institutions, though there was some natural gravitation toward that experience. Participants were asked to leave their process maps on the work tables if they agreed to allow us to use them as data for future research.

\section{Methodology}

During the FIE session, the groups were asked to create a map of the $\mathrm{PhD}$ process, keeping the following questions in mind:

- Who are the Players and how do they relate to each other?

- What are the Milestones?

- What are the Events that impact the outcomes?

Each of the group-created maps were photographed (included in Appendices B-F), then each element on the map was transcribed for easier comparison across the different maps. The maps were compared by process (intellectual and institutional strand), identified characters (network strand), and the potential challenges. These were aligned with each other as well as the original analogy components from the special session (shown in Appendix A) to highlight the similarities and differences between the groups. 
This paper and analysis are limited in their generalizability due to the lack of identified professional characteristics of the groups that generated the maps and variability in participant experiences. However, each map still provides a group mediated description of the processes by the participants. These findings can be utilized as means to compare similar reflections in other contexts and graduate programs.

\section{Findings}

This section will be divided into three sections focused on the different strands of identity-trajectory. Each section will present the elements of the participant maps as well as the elements that were developed for the special session. The challenges that were identified by the participants will be discussed in the respective sections as well.

Institutional. The institutional elements that were identified focus around the specific milestones within the $\mathrm{PhD}$ process that are created by the institution/department that the student is part of. Table 1 shows the different process components identified by the special session facilitators as well as those identified by each of the participant groups. The components were aligned to help identify elements that were present for all groups and places there were gaps or differences between the groups. In general, all of the groups agreed on roughly the following pathway through the $\mathrm{PhD}$ process:

1. Apply and get into graduate school;

2. Complete coursework;

3. Pass Qualifying Exam;

4. Pass Competency/Preliminary Exam;

5. Write Dissertation; and

6. Defend.

These are very common elements across most $\mathrm{PhD}$ programs as reflected by their presence on most, if not all, of the group maps. These are elements that you would likely find in a graduate school manual for the steps to completing a $\mathrm{PhD}$ and are typically the elements that require the completion of some sort of paperwork with the institution to verify that they have been completed. However, there are other implicit elements that are not as directly seen in a manual that are required to meet these steps. For example, choosing an advisor was only explicitly placed on one of the participant group (Group 4) maps. The advisor was included as a character throughout the process or tangential to the process, but the specific act of choosing an advisor was not included as a step in the process by many groups. Choosing your PhD advisor can be one of the most important and influential steps in the $\mathrm{PhD}$ process ${ }^{10}$. The advisor has been identified as being key to the development of the student as researcher and professional in their field; ensuring student success through key functions that provide the student with mentoring, opportunity to collaborate with other colleagues, advocating the student through the process, and correcting negative behaviors. This should be a conscientious step for most students, but it was not explicitly stated by many of the participants. Additionally, forming a committee was also only mentioned by one group (Group 4). Again, the committee was mentioned by most groups as a character element, but the specific step of choosing who would sit on the committee was not. There are important considerations for choosing both an advisor and a committee ${ }^{11}$ and these are critical steps for being successful within in the PhD journey. These decisions are likely a new type of decision for many students as you don't usually get to choose your new supervisor in industry and your advisor likely has a less involved role in the undergraduate setting. Students should feel comfortable talking to faculty and other graduate students in an effort to make an informed and successful decision about who their advisor will be as well as their committee members. 
Table 1.

The institutional components from each map shown in parallel to highlight commonalities and gaps

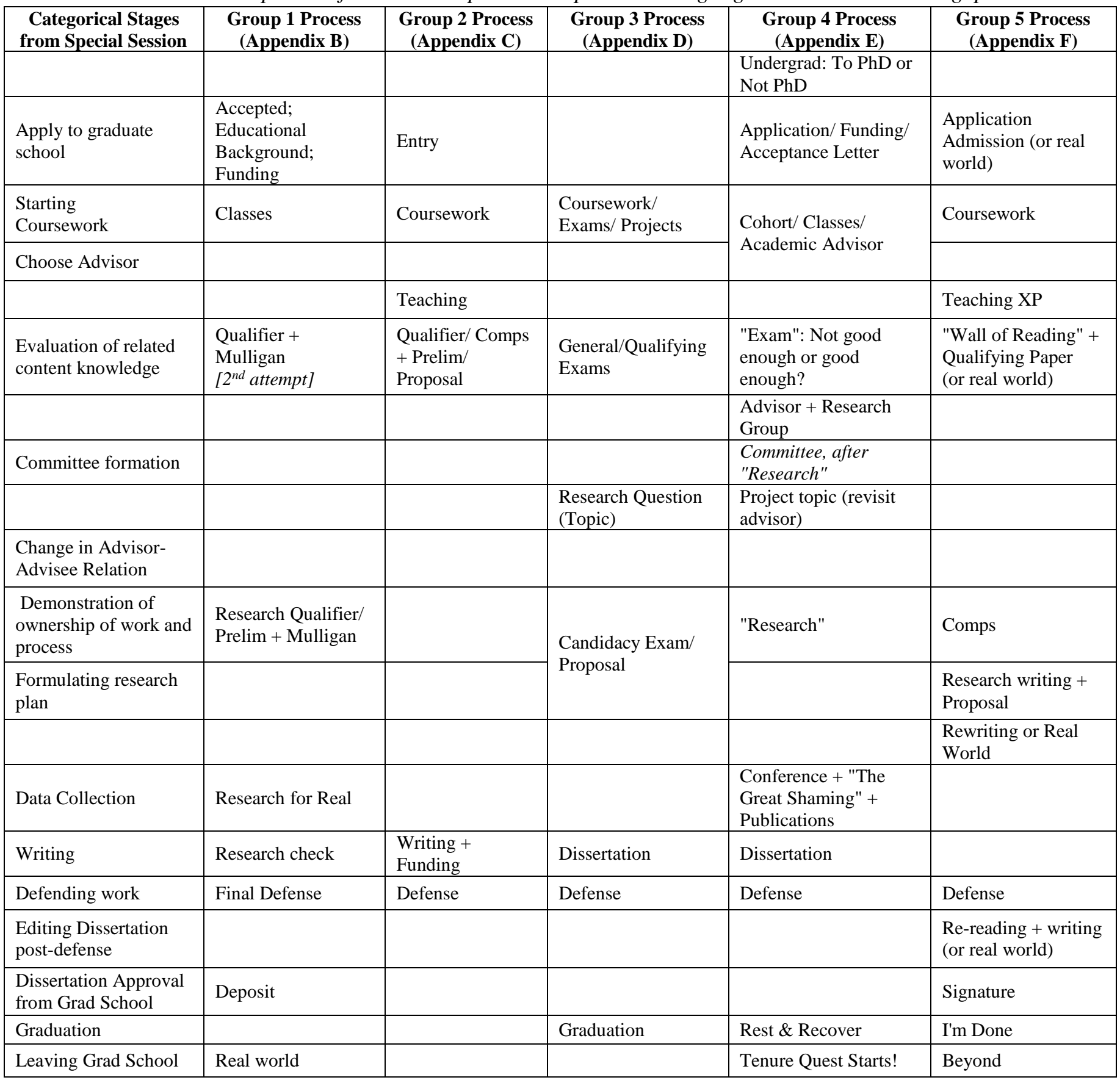

Another implicit element that was not included on many maps (only on Group 5) was the post-defense editing of the dissertation. This can be challenging for students and part of that may be due to its unexpected nature. Again, since this paper is meant to start the conversation about expectations for obtaining a $\mathrm{PhD}$, we wanted to point out this element as one that should be discussed by future students; ensuring revisions from their committee are made before the defense. 
Network. The network elements were framed as the specific characters that were present on each of the group maps. One group (Group 1) focused more on the process and did not list any specific characters or networks that were included in the process. Table 2 outlines the characters included by the other four groups and that were included in the special session analogy. The common players across the groups were:

- Advisor,

- Other graduate students/Cohort, and

- Committee.

Table 2

The network components from each map shown in parallel to highlight commonalities and gaps. Group 1 did not list any specific characters or networks that were included in the process and were not included in this table.

\begin{tabular}{|c|c|c|c|c|}
\hline $\begin{array}{l}\text { Special Session Analogy } \\
\text { Characters }\end{array}$ & Group 2 & Group 3 & Group 4 & Group 5 \\
\hline Advisor & Advisor & Advisor & Advisor & Advisor \\
\hline Fellow graduate students & $\begin{array}{l}\text { Other Grad students in } \\
\text { department }\end{array}$ & Other students & Research group members & Cohort Army \\
\hline $\begin{array}{l}\text { More senior graduate student } \\
\text { who serves as mentor }\end{array}$ & & & $\begin{array}{l}\text { "mentors"; "helpers"; } \\
\text { "guides" }\end{array}$ & Mentors \\
\hline $\begin{array}{l}\text { Committee with specific } \\
\text { contributions to process success }\end{array}$ & Committee & $\begin{array}{l}\text { Committee } \\
\text { Members }\end{array}$ & Committee & Committee \\
\hline \multirow{3}{*}{ Additional Support } & Faculty & & Academic Advisor & \\
\hline & Community & & & \\
\hline & & Family; Friends & & The Call Home \\
\hline
\end{tabular}

These are very common players across all $\mathrm{PhD}$ programs. As we discussed with the institutional elements, the advisor and committee are key elements of a PhD process and can heavily influence the pathways a student takes. Additionally, the support a $\mathrm{PhD}$ student receives from other students can be very influential as this was also identified in some way by all of the groups. It is interesting the variation in how these characters were presented on the maps. Group 4 labeled this group as "research group members" placing a very specific focus on the research component. Group 2 was specific by stating "other grad students in department" placing a specific emphasis on the other students in the department. Group 5 called them a "cohort army" that places specific emphasis on the students that entered the same program in the same year as a cohort. Group 3 left this especially broad as "other students" in general. The variability between groups highlights how PhD students may seek out different peer groups for different kinds of support and that there should be support structures in place to help broaden their socialization. For the analogy, we chose to highlight a more broadly defined "fellow graduate students". We leave this broad as it is important for new student integration to encourage vertical integration within a department while also encouraging socialization across research groups. By having multiple support systems within the graduate community, students can feel more integrated and included to encourage persistence in the program. We do, however, specify that it should be graduate students as it is important for this element that the students understand the $\mathrm{PhD}$ process and what it means to be in a graduate $(\mathrm{PhD})$ program. One player presented in the analogy that was not included in any of the groups was the role of the "Additional Support". In discussions among the participants and facilitators during the session, the additional support was identified as that first person you turn to for support specifically for dealing with $\mathrm{PhD}$ related issues. While this is often times another $\mathrm{PhD}$ student, it may also be a spouse, significant other, or family member. The important attribute of the additional support is that they will help you in every way they can, but they cannot complete the work for you. 
As highlighted by the variation across the groups, there are a number of different players that vary for each student's PhD pathway. The role of non-advisor mentors, the influence of family and friends, as well as the overall influence of the academic community will vary and contribute to or divert from the journey to a $\mathrm{PhD}$. It is important for students to consider the players that are influencing their progress on their journey and evaluate the benefits and consequences of these relationships. What is missing from your $\mathrm{PhD}$ journey if you do not talk to other graduate students within your department? How could being a part of the larger academic community add to or detract from obtaining your $\mathrm{PhD}$ ?

Intellectual. The intellectual strand was the least explicitly discussed across the maps. Group 4 and Group 2 were the only two to explicitly include the broader academic community as part of their maps. Group 2 included "Community" as one of the players within their map. Group 4 referenced "Conferences + 'The Great Shaming' + Publishing" as part of the process to degree. The other intellectual elements were more implicit like Group 5 referencing the "Wall of Reading" or becoming familiar with the previous research within the field.

Overall, the intellectual elements of being part of the larger academic field were limited to reading and research. However, this is an important element for students to think about with respect to presenting at conferences, publishing articles, broader networking outside of your institution, and being active within a professional society.

Obstacles to completing the journey. In addition to illustrating the pathway to a $\mathrm{PhD}$, many groups also highlighted challenges and obstacles that can cause that journey to end prematurely (without the degree). Many of these challenges were noted at the major milestones, such as the qualifier and the candidacy exam. However, other challenges noted included the persistence or lack of funding at any time during the process. Group 5 also noted "Others passing you by" which can be discouraging and is something that is not common in the undergraduate journey where you move through the process mostly as a cohort and in large enough numbers that variability is expected. The $\mathrm{PhD}$ process is very individualized and the rate that you reach the end will be dependent on a number of factors specific to you and your process.

Within the Special Session Analogy and discussion with participants, there were multiple points that were explicitly noted as implicit elements that can slow you down. An example of this was the idea of "Taking ownership of your dissertation." This is important and is characterized as when you feel confident in your knowledge of your dissertation topic to push back and say "No. I'm doing it this way for these reasons" when your advisor or committee says "maybe you should do it this way instead." This is not implying that students should commonly argue with their advisors, but there is a point where they need to be the one making decisions about the future of the project. Each student must realize it is their responsibility to complete their dissertation and that they are training to become the foremost expert on their specific topic. Additionally, many graduate students will face a "change in the advisor-advisee relationship." This can happen for a variety of reasons, generally associated with advisors having careers and journeys that advance in tandem with the student's PhD process. The advisor may earn tenure during the student's time in the program potentially changing the advisor's priorities, thus changing the overall relationship. Similarly, the advisor may leave the institution, resulting in a number of potential relationship-altering scenarios. Again, this will vary, but students should be aware that this can happen and be ready to adapt. There can also be "unexpected obstacles that require changes to the proposal or project." Typically, when collecting data a PhD student may need to adapt to meet the new circumstances in a way that is different than what they intended with their proposal. Maybe the response rate was too low on a survey or the data 
collection site you planned, changed their mind, possibly without telling you. This requires the $\mathrm{PhD}$ students to be adaptable and to work with their committee to ensure that the changes made to this process are acceptable and will lead to a successful dissertation. Every research project will likely differ from the plan in some way, so learning how to appropriately adapt is part of the $\mathrm{PhD}$ process.

Finally, as also mentioned by Group 5 on their map, the actual writing of a dissertation is hard as is the editing and post-defense revising. There is a focus on overcoming the exam elements of the process, but more students leave PhD programs after the coursework is complete and they have entered the "ABD: All But Dissertation" stage of the process ${ }^{7}$. In general, campuses have Writing Centers that are available to help students with editing their writing and there are a variety of resources for how to be productive writing your dissertation. Additionally, writing groups can help students to focus on the writing elements to help with this difficult phase.

\section{The Story}

From our quick study here, we found that many of the more explicit elements of a $\mathrm{PhD}$ process, like those that would be present in the graduate student manual were more consistent across group maps. However, the more implicit elements were frequently overlooked. There are also a number of common challenges that are not readily part of $\mathrm{PhD}$ pathway discussions. Upon further exploration, it was discovered that The Lord of the Rings provides a sample of a "hero journey" as described in contemporary literature. The "hero journey"12 provides a framework for understanding the stages of completing a complex task affected by several characters and challenges that allow the hero to progress along the journey. Using other implementations of the hero journey, additional parallels could be established to find new ways to continue the conversation about graduate education as well as other topics. This can help to illuminate the less discussed challenges or topics in a way that is fundamentally relatable for many audiences. ${ }^{12}$ For example, using the $\mathrm{PhD}$ process as a common element, how does Frodo's journey to Mordor ${ }^{2}$ compare to Luke Skywalker's journey to becoming a Jedi ${ }^{13}$ ? What are the element they have in common and how do the differences influence our view on the $\mathrm{PhD}$ process?

\section{To be continued....}

This paper is intended to help start a conversation about the $\mathrm{PhD}$ experience to help new graduate students to have accurate expectations for what the process will be like and how they can best navigate it. With that goal in mind, here are a few discussion points that can be shared between students, advisors, and the broader graduate community:

- What are the major milestones for this department?

- What support systems are in place to help students meet each milestone successfully?

- What social supports (formal or informal) are in place within the department or university?

- I hear _ can happen during the dissertation process. Is that something you have seen? What could we do to overcome this or avoid it all together?

Good communication between an advisor/advisee and among various graduate students can help to navigate some of these challenges and encourage a successful experience for the students. 


\section{References}

1. Tolkien, J.R.R. (1967). The lord of the rings. Boston: Houghton Mifflin.

2. Cutler, S., Pembridge, J., Verleger, M., \& Thomas, L. (2013). The lord of the PhD: Fellowship of the dissertation - A guide to surviving the pursuit of a PhD. 2013 IEEE/ASEE Frontiers in Education Conference (FIE), Oklahoma City, OK.

3. McAlpine, L. \& Lucas, L. (2011). Different places, different specialisms: similar questions of doctoral identities under construction. Teaching in Higher Education, 16(6), 695-706.

4. Thomas, L. (2014) Identity-trajectory as a Theoretical Framework in Engineering Education Research. $121^{\text {st }}$ ASEE Annual Conference \& Exposition, Indianapolis, IN.

5. Lindsay, E., \& Paterson, K. (2010). Special Session - It's a jungle safari out there: An allegory for learning to navigate academia. 2010 IEEE/ASEE Frontiers in Education Conference (FIE), Washington, D.C.

6. Sowell, R. (2008). Ph.D. Completion and Attrition: Analysis of Baseline Demographic Data. The NSF Workshop: A fresh look at Ph.D. education. Retrieved from: http://www.phdcompletion.org/resources/CGSNSF2008_Sowell.pdf

7. Stallone, M. (2004). Factors associated with student attrition and retention in an educational leadership doctoral program. Journal of College Teaching \& Learning, 1(6), 17-24.

8. Golde, C., \& Dore, T. (2001). At cross purposes: What the experiences of today's doctoral students reveal about doctoral education. Washington, D.C.: U.S. Department of Education.

9. Lovitts, B., \& Nelson, C. (2000). The hidden crisis in graduate education: Attrition from Ph.D. Programs. Academe, 86(November-December), 44-50.

10. Barnes, B.J., \& Austin, A.E. (2009). The role of doctoral advisors: A look at advising from the advisor's perspective. Innovation in Higher Education, 33, 297-315.

11. Pembridge, J., \& Cutler, S., (2013). Assembling the ideal doctoral dissertation committee in engineering education. $120^{\text {th }}$ ASEE Annual Conference \& Exposition, Atlanta, GA.

12. Robbins, R.A. (2005). Harry Potter, ruby slippers and Merlin: Telling the client's story using the characters and paradigm of the archetypal hero's journey. Seattle University Law Review, 29, 767-803.

13. Kurtz, G., \& Lucas, G. (1977). Star Wars. United States of America: Twentieth Century Fox Film Corporation. 
Appendix A: Adapted handout from the FIE workshop - completed with analogy elements. All The Lord of the Rings (LotR) characters and plot points have been summarized based on the book/movie. ${ }^{1}$

$$
\begin{gathered}
\text { Identity Trajectory: } \\
\text { - Individual } \\
\text { - Institutional } \\
\text { - Network }
\end{gathered}
$$

\begin{tabular}{|c|l|l|}
\hline Character & \multicolumn{1}{|c|}{ LotR Character Description } & \multicolumn{1}{c|}{ Role in the PhD Process } \\
\hline Frodo & $\begin{array}{l}\text { The ring bearer - Is responsible for } \\
\text { carrying the ring to Mordor and } \\
\text { casting it into the fires of Mt. Doom. }\end{array}$ & $\begin{array}{l}\text { You, the PhD student (or Your PhD student, if you } \\
\text { are an advisor). }\end{array}$ \\
\hline Gandalf & $\begin{array}{l}\text { The wizard - Sets Frodo on his } \\
\text { journey to Mordor and acts as a } \\
\text { guide along the way. }\end{array}$ & The PhD advisor. \\
\hline Sam & $\begin{array}{l}\text { The loyal hobbit - Accompanies } \\
\text { Frodo from the Shire to Mt. Doom } \\
\text { and back. Never leaving his side. }\end{array}$ & $\begin{array}{l}\text { Additional support. Typically, one or two specific } \\
\text { people who you quickly turn to for support during } \\
\text { PhD process. }\end{array}$ \\
\hline Merry \& Pippin & $\begin{array}{l}\text { Also hobbits - Are friends with Frodo } \\
\text { and Sam and set out to accompany } \\
\text { them on their quest. }\end{array}$ & $\begin{array}{l}\text { Fellow graduate students. Like your cohort or } \\
\text { research group. }\end{array}$ \\
\hline Aragorn (Strider) & $\begin{array}{l}\text { King of men/ranger - Meets the } \\
\text { hobbits and leads them to Rivendell, } \\
\text { then joins the quest to Mordor. }\end{array}$ & $\begin{array}{l}\text { More senior graduate student who serves as } \\
\text { mentor. Able to guide graduate student through the } \\
\text { process. }\end{array}$ \\
\hline
\end{tabular}

\begin{tabular}{|l|l|l|}
\hline \multicolumn{1}{|c|}{ Event } & \multicolumn{1}{c|}{ LotR Event Description } & \multicolumn{1}{c|}{ Milestone in the PhD Process } \\
\hline Hobbiton & $\begin{array}{l}\text { Hobbits happily celebrate at a } \\
\text { birthday party before they know the } \\
\text { quest before them }\end{array}$ & Starting the PhD: Master's and coursework. \\
\hline $\begin{array}{l}\text { Frodo receives the ring } \\
\text { from Gandalf }\end{array}$ & $\begin{array}{l}\text { Gandalf asks Frodo to take the ring to } \\
\text { Rivendell for safe keeping }\end{array}$ & $\begin{array}{l}\text { Choosing advisor and deciding to take on the } \\
\text { dissertation process. }\end{array}$ \\
\hline Weathertop & $\begin{array}{l}\text { The hobbits are attacked by the Ring } \\
\text { Wraths. Frodo is stabbed in the } \\
\text { shoulder. }\end{array}$ & $\begin{array}{l}\text { Evaluation of related content knowledge - the } \\
\text { qualifier or competency exam. }\end{array}$ \\
\hline
\end{tabular}


Act 2

\begin{tabular}{|c|l|l|}
\hline Character & \multicolumn{1}{|c|}{ LotR Character Description } & \multicolumn{1}{c|}{ Role in the PhD Process } \\
\hline Gimli and Legolas & $\begin{array}{l}\text { Represent the dwarf and elf race, } \\
\text { respectively, as part of the } \\
\text { fellowship. }\end{array}$ & $\begin{array}{l}\text { Committee members with specific skills that } \\
\text { contribute to completing your PhD. }\end{array}$ \\
\hline
\end{tabular}

\begin{tabular}{|c|l|l|}
\hline Event & \multicolumn{1}{|c|}{ LotR Event Description } & \multicolumn{1}{c|}{ Milestone in the PhD Process } \\
\hline Rivendell & $\begin{array}{l}\text { It is decided that the ring must be destroyed in } \\
\text { Mt. Doom and a fellowship is formed to take it } \\
\text { there. Frodo is officially the ring bearer. }\end{array}$ & Forming your committee. \\
\hline
\end{tabular}

\section{Act 3}

\begin{tabular}{|l|l|l|}
\hline \multicolumn{1}{|c|}{ Event } & \multicolumn{1}{|c|}{ LotR Event Description } & \multicolumn{1}{c|}{ Milestone in the PhD Process } \\
\hline $\begin{array}{l}\text { Moria/the } \\
\text { Balrog }\end{array}$ & $\begin{array}{l}\text { While on their journey, the fellowship ventures } \\
\text { into the mines of Moria encountering many } \\
\text { foes. Gandalf faces the fiercest of foes and falls } \\
\text { into the abyss. }\end{array}$ & $\begin{array}{l}\text { Change in the advisor/advisee relationship. For } \\
\text { example, the advisor gets tenure or takes an } \\
\text { appointment at another institution. }\end{array}$ \\
\hline Amon Hen & $\begin{array}{l}\text { Orcs attack the fellowship in search of the ring. } \\
\text { Frodo leaves the fellowship to take the ring to } \\
\text { Mordor alone, but Sam follows. }\end{array}$ & $\begin{array}{l}\text { The PhD student takes ownership of their } \\
\text { dissertation. }\end{array}$ \\
\hline $\begin{array}{l}\text { Meeting } \\
\text { Smeagol/ } \\
\text { Gollum }\end{array}$ & $\begin{array}{l}\text { Gollum wants the ring for himself, so he follows } \\
\text { Sam and Frodo. He is captured and agrees to } \\
\text { guide Frodo to Mordor. }\end{array}$ & $\begin{array}{l}\text { The proposal. Making a plan to figure out how to get } \\
\text { from where you are to the end of your dissertation. }\end{array}$ \\
\hline
\end{tabular}

Act 4

\begin{tabular}{|c|c|c|}
\hline Event & LotR Event Description & Milestone in the PhD Process \\
\hline $\begin{array}{l}\text { Trapped by } \\
\text { Shelob }\end{array}$ & $\begin{array}{l}\text { Frodo is on his own on the way to Mordor and } \\
\text { is trapped by a Giant Spider named Shelob, } \\
\text { who tries to eat him. }\end{array}$ & $\begin{array}{l}\text { Something unexpected that slows you down - } \\
\text { typically something that goes wrong with your } \\
\text { proposal. For example: not recruiting enough } \\
\text { participants, inconclusive results that require a } \\
\text { second phase to be added to your study. }\end{array}$ \\
\hline $\begin{array}{l}\text { Climbing Mt. } \\
\text { Doom }\end{array}$ & $\begin{array}{l}\text { Frodo has made it to Mordor, but still has to } \\
\text { make it up the mountain. The pull of the ring is } \\
\text { strongest here. }\end{array}$ & $\begin{array}{l}\text { Writing. This is when it is helpful to have a "Sam" to } \\
\text { support you and carry you (not the ring) closer to } \\
\text { then end. }\end{array}$ \\
\hline $\begin{array}{l}\text { Inside Mt } \\
\text { Doom }\end{array}$ & $\begin{array}{l}\text { Though Frodo stands on the brink of } \\
\text { completing his quest, he attempts to take the } \\
\text { ring and walk away }\end{array}$ & Defending and editing your dissertation. \\
\hline $\begin{array}{l}\text { Destroying } \\
\text { the ring }\end{array}$ & $\begin{array}{l}\text { The ring falls into the fires of Mt. Doom and is } \\
\text { destroyed along with Sauron and his forces. }\end{array}$ & $\begin{array}{l}\text { Everything is submitted and accepted by the } \\
\text { graduate school! }\end{array}$ \\
\hline $\begin{array}{l}\text { Frodo leaves } \\
\text { with the } \\
\text { Elves }\end{array}$ & $\begin{array}{l}\text { Having completed his quest, Frodo leaves } \\
\text { Middle Earth to travel with the Elves to their } \\
\text { homeland in the west. }\end{array}$ & $\begin{array}{l}\text { Graduation - The graduate student is no longer a } \\
\text { graduate student and goes on to become a faculty } \\
\text { member/grown up. }\end{array}$ \\
\hline
\end{tabular}


Appendix B: Group 1 Map

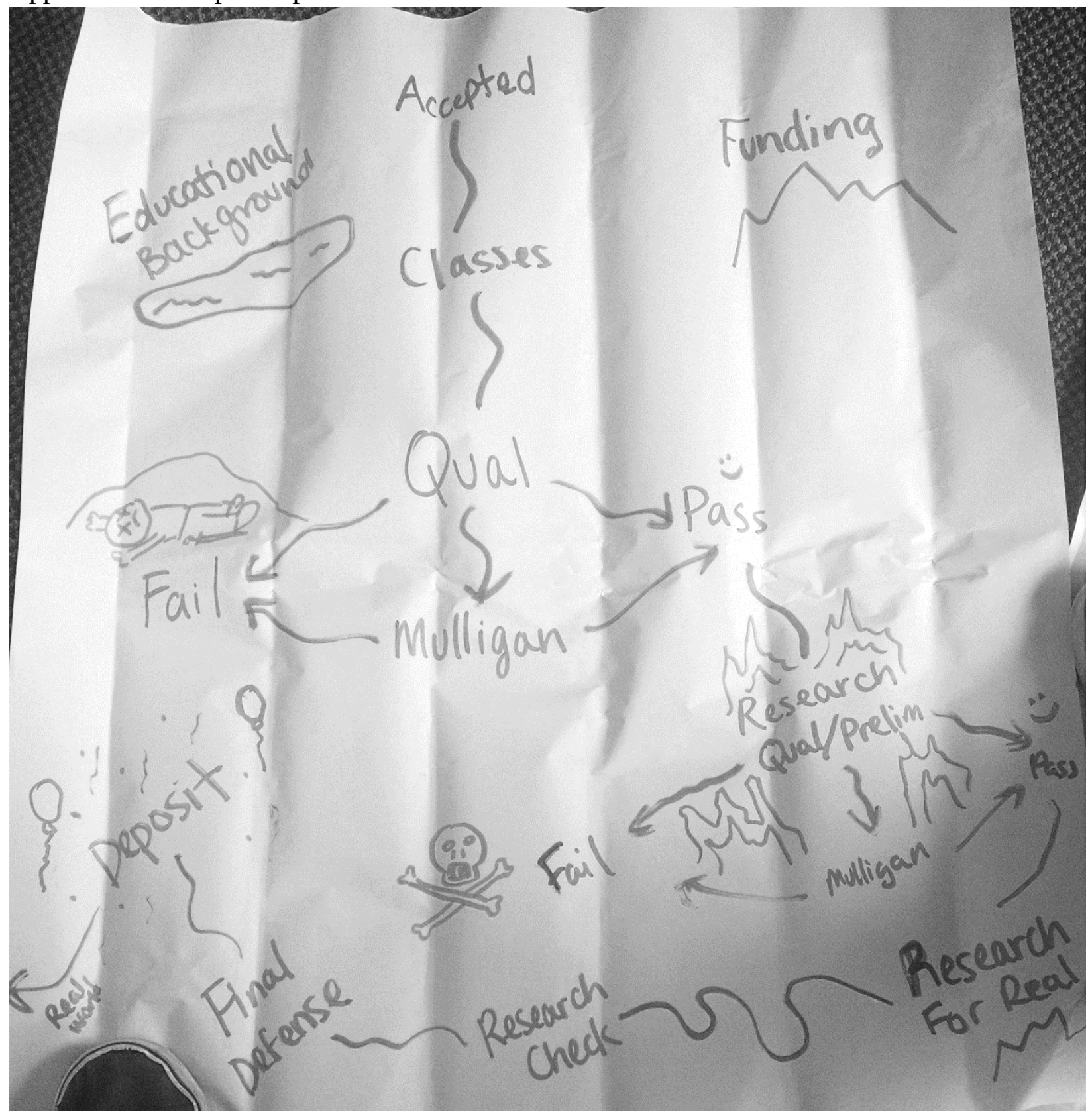


Appendix C: Group 2 Map

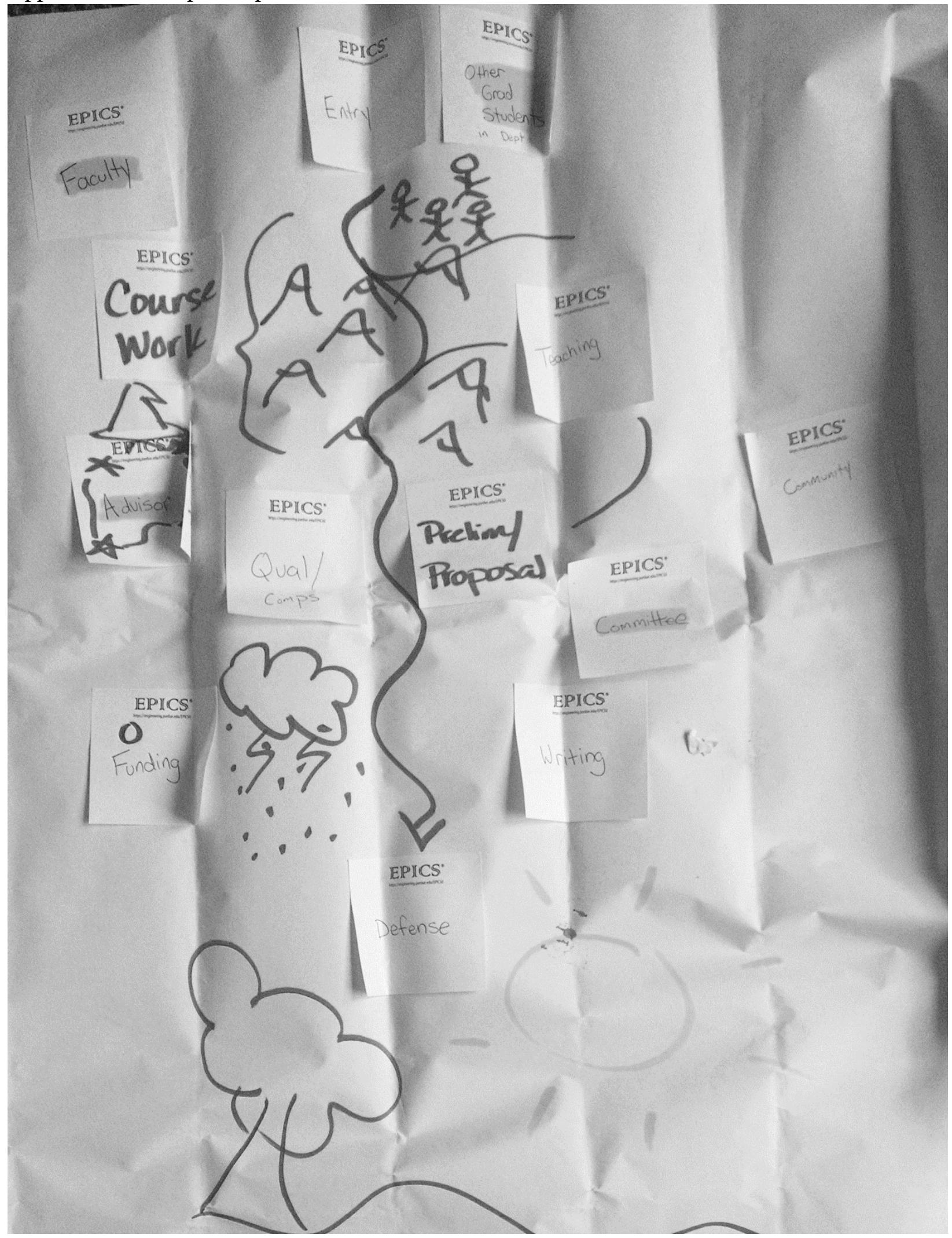

Appendix D: Group 3 Map 


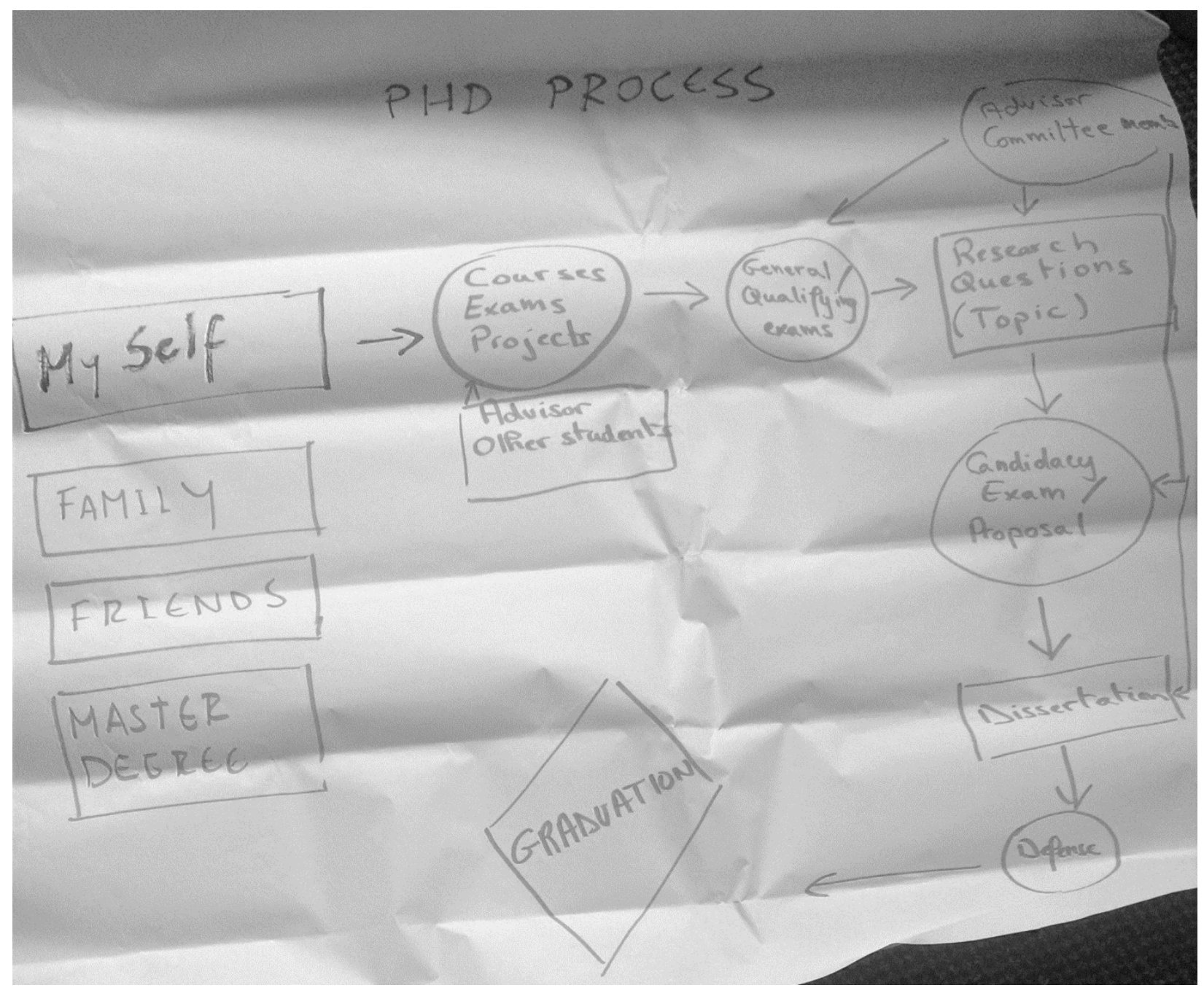


Appendix E: Group 4 Map

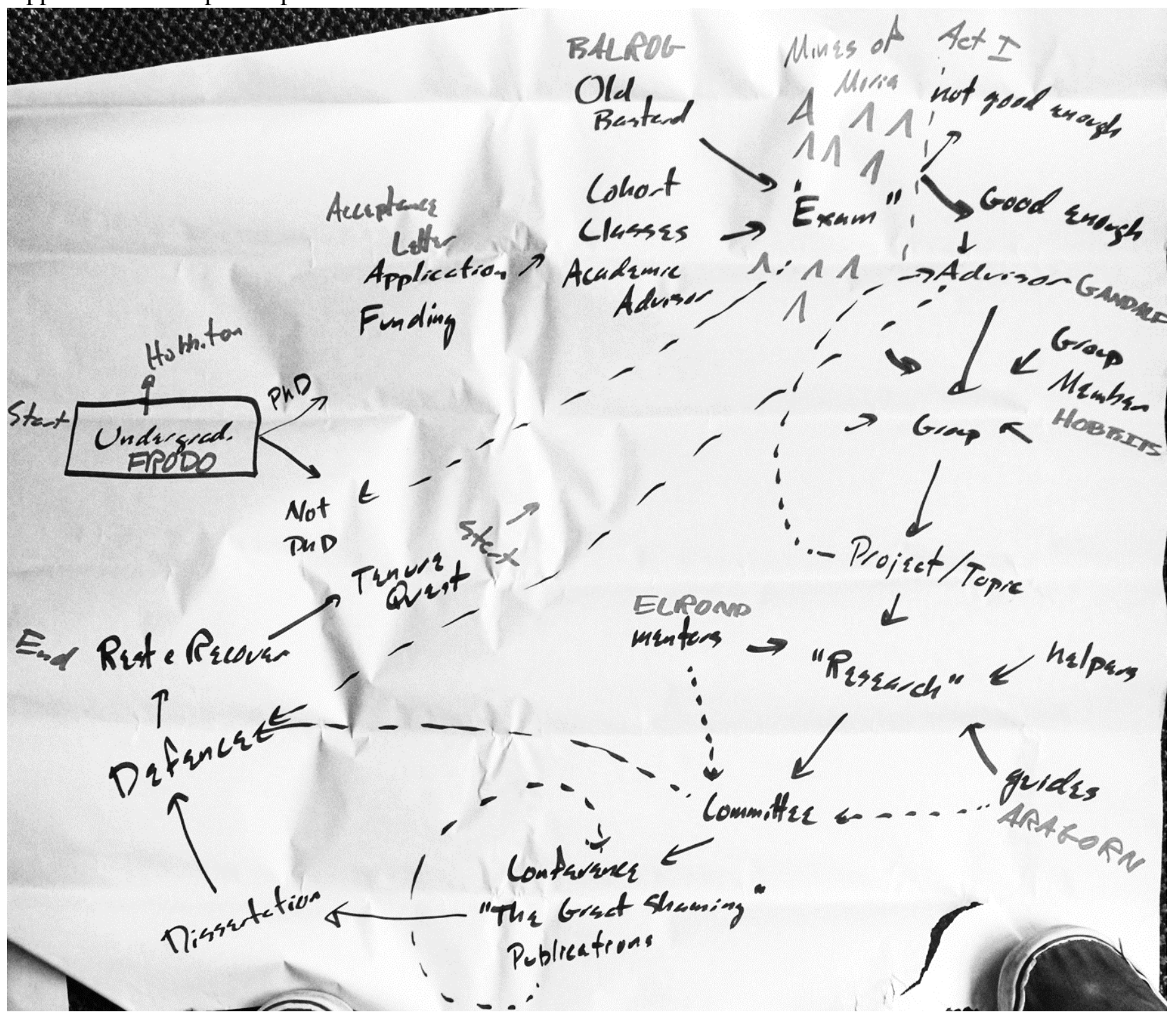




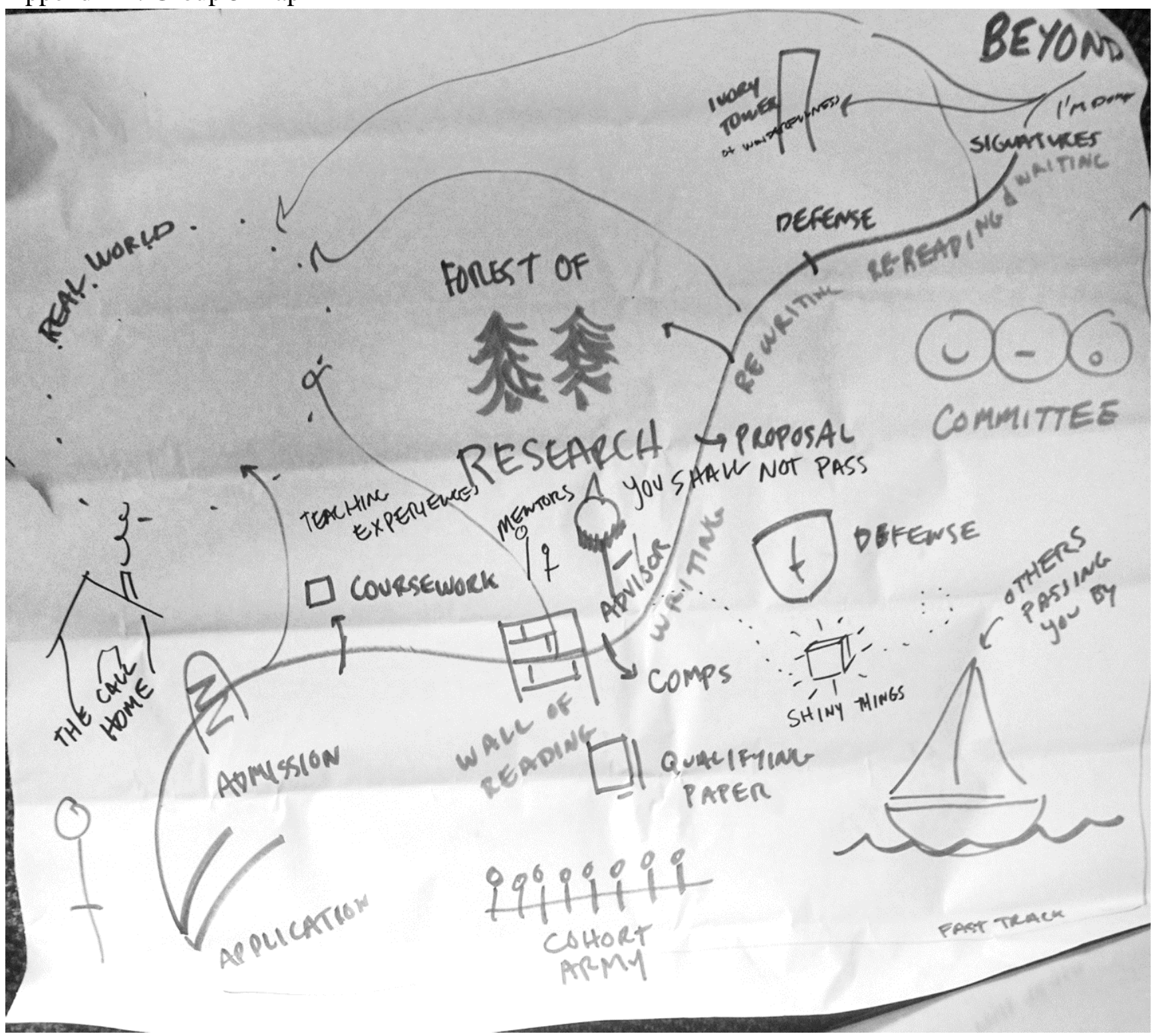

